Jurnal ASPIKOM, Vol. 7, No. 1, January 2022, pp. 202-218

P-ISSN: 2087-0442, E-ISSN: 2548-8309

DOI: http://dx.doi.org/10.24329/aspikom.v7i1.996

\title{
MSMEs' Strategy for Delivering Messages through TikTok Content
}

\author{
M. Rifqi Fauzan Adyatma \\ Universitas Mercu Buana, Jalan Meruya Selatan, Kembangan, Jakarta Barat, Indonesia \\ *Corresponding author, e-mail: adyatmarifqi@gmail.com
}

\begin{abstract}
Competition between large companies and small businesses such as Micro, Small, and Medium Enterprises (MSMEs) is unavoidable. Quoting from previous research, MSME actors lack knowledge, funding, and time which may hamper their marketing communications. Content marketing through TikTok is now an option. The purpose of this study was to determine the model of the message delivery strategy through TikTok carried out by MSME actors referring to the theory of new media and content creation elements. This research uses a qualitative approach with a case study method. Data collection was carried out by interviewing eight MSME actors who use TikTok as a means of marketing communication. The results show that the target market is Generation $Z$, the content presented focuses on trends, the communication style is carried out by indirect marketing with diverse content schedules, and customer engagement through comments is very important.
\end{abstract}

Keywords: Message delivery strategy; New media theory; MSMEs; Content distribution platform; TikTok

\begin{abstract}
Abstrak
Persaingan antara perusahaan besar dengan bisnis kecil seperti Usaha Mikro Kecil dan Menengah (UMKM) tidak dapat dihindari. Mengutip dari penelitian sebelumnya, Pelaku UMKM memiliki kekurangan pengetahuan, pendanaan dan waktu yang menghambat untuk melakukan komunikasi pemasaran. Pemasaran konten melalui TikTok saat ini menjadi pilihan. Tujuan penelitian ini adalah untuk mengetahui model strategi penyampaian pesan melalui TikTok yang dilakukan oleh pelaku UMKM mengacu pada teori media baru dan elemen pembuatan konten. Penelitian ini menggunakan pendekatan kualitatif dengan metode studi kasus. Pengumpulan data dilakukan dengan mewawancarai delapan pelaku UMKM yang menggunakan TikTok sebagai sarana komunikasi pemasaran. Hasil penelitian menunjukkan target pasar adalah generasi $Z$, konten yang disajikan fokus pada tren, gaya komunikasi yang dilakukan pemasaran tidak langsung dengan jadwal konten yang beragam dan keterlibatan pelanggan melalui komentar menjadi sangat penting.
\end{abstract}

Kata Kunci: Strategi penyampaian pesan; Teori new media; UMKM; Platform distribusi konten; TikTok

Article History: Received June 28, 2021; Revised November 10, 2021; Accepted November 22, 2021 


\section{Introduction}

Market competition in business is getting more challenging. Not only big companies are competing, but small businesses such as Micro, Small, and Medium Enterprises (MSMEs) also contribute to enlivening this business competition. Large companies are certainly already known by the public, thus do not need very intense marketing communications to be recognized. However, the unknown MSME actors must introduce their products regularly despite many shortcomings, ranging from knowledge, funding, and time (Kraus et al., 2019).

So that the products or services of MSME actors can reach many customers and be known by the public, promotional activities must be carried out. Promotion is carried out by conducting marketing communications with product introductions, establishing relationships with the audience, and creating interactions (Kusniadji 2016). Marketing communication is always evolving, starting from its conventional nature up to the present time to the digital era. Conventional communication is usually more expensive and difficult to spread, but the result is also not effective for increasing awareness and sales. Meanwhile, in the current digital era, social media has become an inseparable part of people's daily consumption. MSME actors can use this to introduce their business digitally using social media, with minimal costs and maximum results.

Today's social media is very much starting from Youtube, Facebook, Twitter, and Instagram. Meanwhile, the most widely used social media for businesses is Instagram as the main platform to market their products(Simangunsong 2021). Lately, the use of TikTok has been trending by social media users. In February 2020, TikTok itself gained 800 million users from all over the world (Dilon 2020). Until now, it continues to grow. Even a lot of content shared on TikTok will also enter Instagram, Twitter, and even Youtube because the content is in the form of videos and is flexible for all platforms. Content with its own video format has the highest participation rate. With video content, business people can explain specific issues, demonstrate products or services, and present interesting topics according to the target audience (Vinerean 2017).

TikTok itself is not social media. Social media always focuses on the number of followers, but TikTok is a content distribution platform. Without a large number of followers, MSMEs can spread our content to many people. This research is new because many previous studies only discussed social media platforms and were carried out on large companies. While in this study, we will discuss the latest platform, namely the content distribution platform, and a smaller business scale, namely MSMEs.

Previous research conducted by (Kraus et al., 2019) discusses how important content creation is for MSMEs with limited resources. Each MSME from each country also has a different approach to social media, such as research conducted by (Öztamur and Karakadilar 2014). The use of social media has a very positive impact on financial performance for MSMEs due to a reduction in marketing costs (Ainin et al., 2015). The use of TikTok by athletes can increase their self-branding to connect directly with fans ( $\mathrm{Su}$ and Baker 2020). From the existing research, no direct research discusses the message delivery strategy carried out by MSME actors, especially using content distribution platforms. This is important to help MSME actors because the national economy is very dependent on this MSME business which has an important and strategic role(Sarfiah, Atmaja, and Verawati, 2019).

Although TikTok is not a social media like Facebook and Instagram, the use of TikTok as marketing is currently a trend. Inspirational stories on a website 
https://www.tiktok.com/business/id/inspiration show a variety of well-known brands that has added TikTok to their websites, such as, Shopee, Bibit, Clean and Clear, Universal Studio, Guess, and many other well-known brands that have finally made TikTok their marketing medium. TikTok helps brands achieve marketing success (TikTok, 2020). TikTok has a timeline called FYP (for you page) which contains recommended content that users can watch. With this timeline, TikTok provides all the content users are interested in by looking at big data about those users.

The important thing for a content distribution platform is, of course, content. Therefore, MSME actors must be able to create exciting and persuasive content. A persuasive communication process can be effective if communicators, communicants, and persuasive messages. (Putri et al., 2015). Therefore, in addition to marketing through content and the platform used, the design of a message needs to be done by MSME actors to influence someone to buy something. SMEs must be able to understand a problem(Derin et al. 2020), design approach (Warren, Becken, and Coghlan 2017), and word choice (Dian 2019) the right way to convey a persuasive message.

According to Hermawan in (Ri'aeni 2019), Integrated Marketing Communication (IMC) is a process that integrates planning, action, and coordination in marketing communications and understanding the consumer. Therefore, SMEs must plan, take action, and understand their consumers. On the theory of new media expressed by Flew in (Indrawan and Ilmar 2018), New media is a combination of 3 components: communication networks, digital media, and information content. The theory shows that the strength of new media is the media as well as the content. Therefore, to carry out effective communication on a medium, content is needed.

The existence of new media will make it easier to communicate because it is more addressable (Schiffman and Kanuk in Ricko and Junaidi 2019). The message can be explicitly delivered even though other recipients can get the essence of the same message. The message is also interactive because the recipient of the message can interact directly with the communicator and easily pass it on.

Content created by a communicator (MSME actors) must be designed in such a way to persuade their target market. The MSME actors need to design the content of the message, the purpose of the communication, and the way it is delivered so that it conveys a persuasive message that customers can well receive. Studying how they produce messages and communicate these messages is interesting because they have to create the right strategy to persuade the audience. This research is important to do to analyze the message delivery model implemented by MSME actors, especially in the use of the TikTok content distribution platform. Content strategy is needed to become a map to direct content to achieve the wishes of the communicator (Ricko and Junaidi 2019).

According to Kraus et al. (2019), there are several elements in creating content, namely target audience, customer engagement, content quality, content schedule, and communication style. All of these elements will be found in this research. In searching for a marketing communication method used through social media, forming a communication model will help find a form that can explain the phenomenon (Aruman et al., 2017). The communication model represents an object or event that is ideally arranged to describe communication structure (Al-Fedaghi 2012). Therefore, this study focuses on how MSME actors carry out the model of delivering marketing communication messages through content distribution platforms. This study aims to 
formulate a model for delivering messages through TikTok that is suitable for MSMEs.

This study aims to assist MSMEs in creating more effective marketing communication through content distribution platforms such as TikTok. With the message delivery model, it is hoped that MSMEs can compete with other large companies with greater resources than the MSME business. The message delivery model includes the production of messages and the delivery of messages to the audience.

\section{Method}

The researcher applied a qualitative approach with the case study method. The case study research method investigates the phenomenon of the context of life, especially when the boundaries between phenomenon and context cannot be clearly separated. Case study research design deals with the typical situation in which many variables are of interest, depending on multiple data sources with data requiring triangulation and checking with other results (Prihatsanti, Suryanto, and Hendriani 2018).

Research subjects are selected to find something that is sought in accordance with the research focus that has been determined. In this study, researchers examined eight MSME actors who had different types of business as informants, with various provisions as follows:

1. Using TikTok for marketing

2. Using the username according to the business name

3. Have product content videos that have been uploaded via TikTok

Researchers chose eight business people. The article (Guest, Namey, and Chen, 2020) about the saturation of data collection in qualitative research claimed that six informants would produce data majority more recently than subsequent informants, and with six informants, a researcher can identify an existing concept and capture the majority of information in a similar sample. The researcher chose eight business people so that the next two informants were used to confirm and confirm that there was no other new data.

MSME actors as informants in this study referred to Law number 20 of 2008 concerning MSMEs and included businesses with micro, small and medium-sized businesses to understand the three classes' characteristics. The products marketed by MSME actors in this study are clothing, food/beverage, and handicraft products.

Table 1. Research Subjects (source: Observation of research subjects on March 1, 2021)

\begin{tabular}{clccc}
\hline MSME & Account name & $\begin{array}{c}\text { Number of } \\
\text { Uploads }\end{array}$ & $\begin{array}{c}\text { Number of } \\
\text { Followers }\end{array}$ & $\begin{array}{c}\text { Number of } \\
\text { Likes }\end{array}$ \\
\hline A & Goldenbees.id & 32 & 8850 & 274,800 \\
B & craft_itup & 126 & 18,900 & 413,700 \\
C & Byrequestcraft & 74 & 30,400 & 254,100 \\
D & artspace.id & 259 & 122,600 & $1,600,000$ \\
E & ClaudiaProject & 68 & 30,300 & 327,700 \\
F & Honeyboney.id & 120 & 12,600 & 222,200 \\
G & Kimya_id & 378 & 23,600 & 183,600 \\
H & Vinderu.indonesia & 95 & 44,700 & 364,500 \\
\hline
\end{tabular}

Researchers chose the eight MSME actors as informants because all of the informants were very active in using the TikTok application to carry out marketing 
communications. Many of the videos they have uploaded get a lot of views and followers to get many benefits for them. These eight MSME actors even had better performance and success on their TikTok accounts than their other social media accounts such as Instagram, Youtube, and Facebook that they previously had.

\section{Results and Discussion \\ Target Audience}

In order to attract customers more effectively, it is important to know who they are. A marketer must know their target and understand their target market (Weinberg and Pehlivan 2011). Marketing activities through content to be effective must be able to trigger cognitive, emotional, and consumer behavior (Koob 2021). Therefore, a communicator will compose a message that will be used and relevant to delivering a message. In this context, MSME actors will convey messages to their customers or potential customers to provide awareness of the product, interest in it, and commit to purchasing it. At this stage, MSME actors design their own way of communicating when using TikTok by paying attention to their needs and target market. MSME actors certainly understand the platform first. Before creating content or messages, they first understand TikTok starting from the audience. In the research conducted by (Simangunsong 2021), business people who use social media individually, in this case MSMEs, can introduce their products and market their products to various social media platforms and people who use it to develop their networks.

MSME actors in this study saw the TikTok application as an opportunity to communicate their products because the application has high traffic. With regard to the target audience, the algorithm was still easy; there was no need to pay for many people to see, and so on. Therefore, TikTok is the choice compared to other social media, making it increasingly difficult for MSME actors to be "seen" by their potential customers. As the HR owner of the Byrequestcraft account said.

"Why choose TikTok? Because we research TikTok users, many young people match our audience, besides that the Tiktok algorithm is still relatively easy to reach a large audience compared to Facebook and Instagram" (HR Interview, 04/01/2021)

Even though MSMEs understand their target market, they usually understand based on assumptions rather than looking for data that can help them define their target market. (Kraus et al. 2019). Therefore, what they actually see is only from the surface without using certain tools to understand their target market. This is a lack of knowledge from MSME actors to assess their targets.

The target market for MSMEs in this study is Generation Z. Generation Z grows and develops in tandem with digitalization in various aspects. Generation $\mathrm{Z}$ also has the characteristics of growing intelligent, skilled in using technology, creative, and critical. Generation $\mathrm{Z}$ is also interested in something that is considered new, unique, and out of the box, very confident with fast access to information, including what is trending (Christiani and Ikasari 2020). Because the characters of Generation Z are more creative and critical, they do not just see a product from photos. The use of video will make them see the product as a whole from all sides. Therefore, Generation $\mathrm{Z}$ is easier to digest and remember messages conveyed through videos (Christiani and Ikasari 2020). 


\section{Content Quality}

The richness of content is judged by the depth and detail of both information directions between the company and its customers. There is a vital factor in the content's quality (Öztamur and Karakadilar 2014). SMEs must be able to create good information between the company, perhaps in terms of the products offered and from the customer side, to get the attention of these potential customers.

Before producing content, there are several considerations to consider: looking at trends on TikTok, designing what kind of content will be produced, researching articles related to the target market, and looking for ideas. There are several things to look at in paying attention to a trend, namely sound or music, content type, and hashtags. Sound or music and this type of content sometimes have a relationship. A type of content usually has its music, but not infrequently, the MSME actors who are the sources in this study only use one trend, such as the music or the type of content. As said by (Koob 2021), referring to the theory of uses and gratification, someone will look for media that meet their needs and direct them to satisfaction. In this case, the content must be functional (about brands, education), hedonic (entertainment, relaxation), or separate motives (identity construction, self-confidence).

The results of observations made by the author, trends in sound or music contain popular music ranging from western, Korean songs to Indonesian songs currently popular on TikTok. Not only music or songs but also other sounds such as dialogue and voice-over that are currently popular and can be used by all TikTok users to use through their videos. Trends in this type of content usually contain dialogue, storytelling, dance, transitions, sketches, or even educational content that is wrapped in interesting and usually tied to a certain sound or music. Trends in hashtags are obtained from the search feature in TikTok. On the menu appears some popular content related to certain hashtags, a company can make these hashtags for marketing activities, or indeed the hashtag is currently popular among TikTok users.

MSME actors create content that is similar to an existing trend. For example, based on the types of content that exist, they will try to imitate the same content by changing the context of their business, selling, tips, or adapting to their target audience. As said by DM, the account owner Kimya.id,

"Creating content on TikTok, look at the trend, first see what the trend is, which is currently trending again and is viral. After that, almost similar content is created, but the contents are selling such as tips, introducing products". (DM interview, 20/01/2021)

The trend here is very important because this is momentum so that the content that MSME actors have will spread to other TikTok users. Being too late to catch the trending moment will affect the spread of the content to TikTok users, resulting in fewer viewers. Therefore, searching for content ideas is quite important because MSME actors must always be connected to social media. The content they produce will continue to be exposed to their audience until finally, they are willing to buy products from MSME actors. However, the idea itself is the biggest challenge for MSME actors in this study, especially for those who do everything themselves and do not have a team. The idea for content is a big barrier for them. This is because the characteristics of MSME actors are limited financial and human resources (Bengtsson and Johansson 2014). As BA, the owner of the Goldenbees.id account, said 
"Content ideas are the most difficult because you have to work on and think about it yourself. In contrast to companies with a special social media division, MSMEs have to do everything themselves, starting from Instagram, TikTok, Marketplace, and Everything. Looking for content ideas always takes time and energy"

Therefore, the MSME actors in this study have their way of looking for an idea that they can create for their content, which is as follows:

\section{For your page (FYP)}

MSME actors watch videos on their FYP, focusing on finding out what is trending right now. They use the observe, imitate, and modify (ATM) method to stay abreast of existing trends. They only need to relate existing content to their products, so they do not have to think about their content from scratch thoroughly. They only need to imitate and modify existing ones.

2. Google

For those whose content is focused on education, they get their ideas through articles found on the Google search page

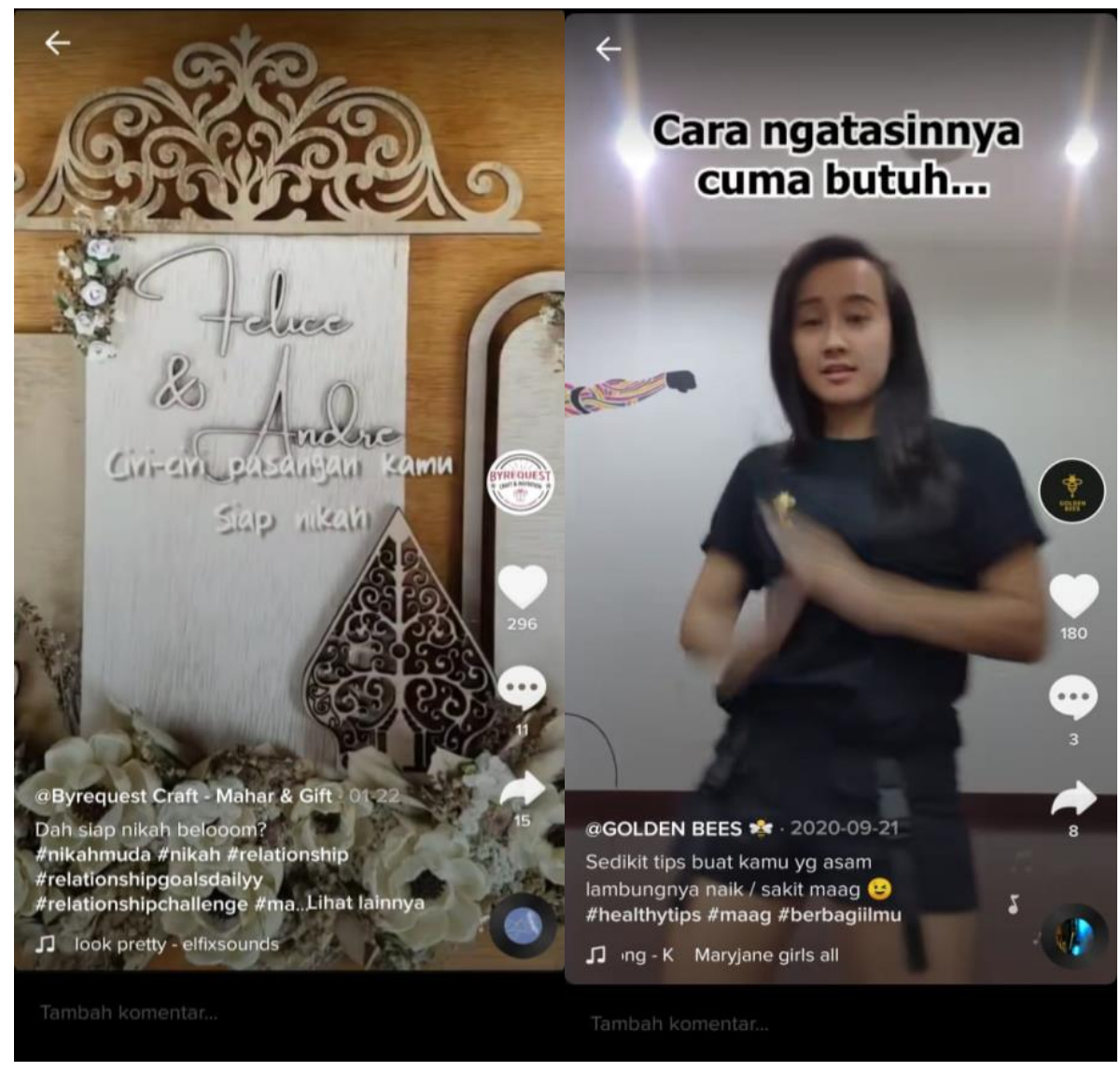

Figure 1. Educational content obtained from Google (source: TikTok accounts @ ByrequestCraft and @GoldenBees)

3. Other social media

Social media such as Twitter, Facebook, Instagram, and Youtube can be content ideas for MSME actors. Starting from seeing competitors, trending, educational content, and others that can be obtained through other social media to change the delivery through TikTok. 


\section{Everyday life}

The closer and closer to the audience, the more interested the audience is, for example, about partners, heartbreak, touching messages, or personal experience stories can be interesting content for MSMEs so that they have an immediate sense of closeness to the content. According to Robin in Savitri and Irwansyah (2021), showing emotion is the most popular type of storytelling in the digital world, one of which is telling someone's experience. In this context, SMEs can share their stories about their experiences in business. This is also said by Wuebben in (Vinerean 2017) that stories from businesses can be the key to content.

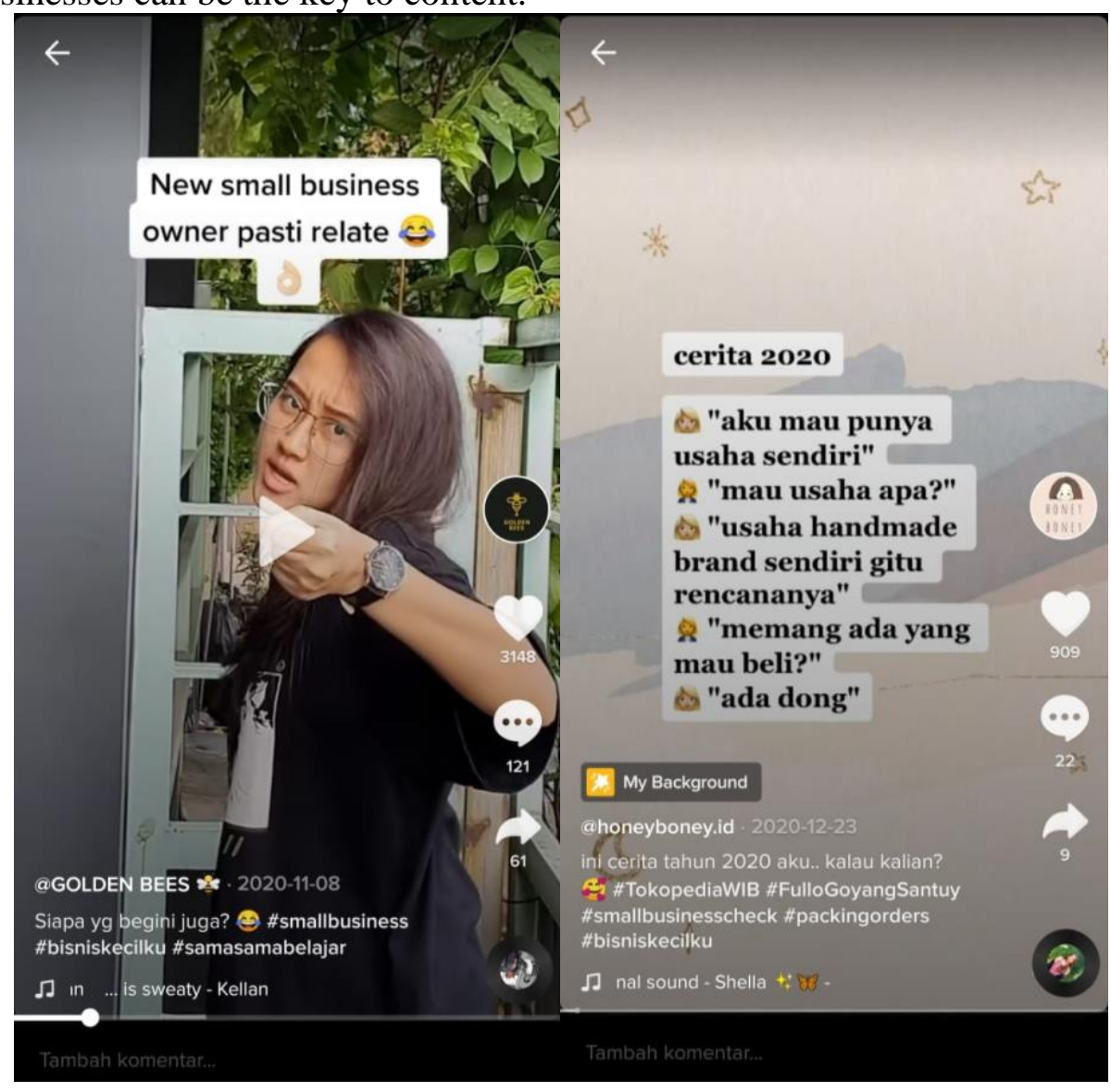

Figure 2. Content from everyday life (source: TikTok account @ GoldenBees and @HoneyBoney.id)

\section{Comment}

Content through this comment will make the audience feel like friends because their comments are replied. Also, if the MSME reply using a video, the source (audiences) will feel like they are participating in the content and attract other people to make similar comments to make videos. Moreover, the audience can also ask for any kind of content, and the MSME actors will make that. The comments contain the audience's request to know more about the products offered by the audience, according to their needs. Audience-requested content closer to the audience will usually be shared by more people who are equally connected to the content. 


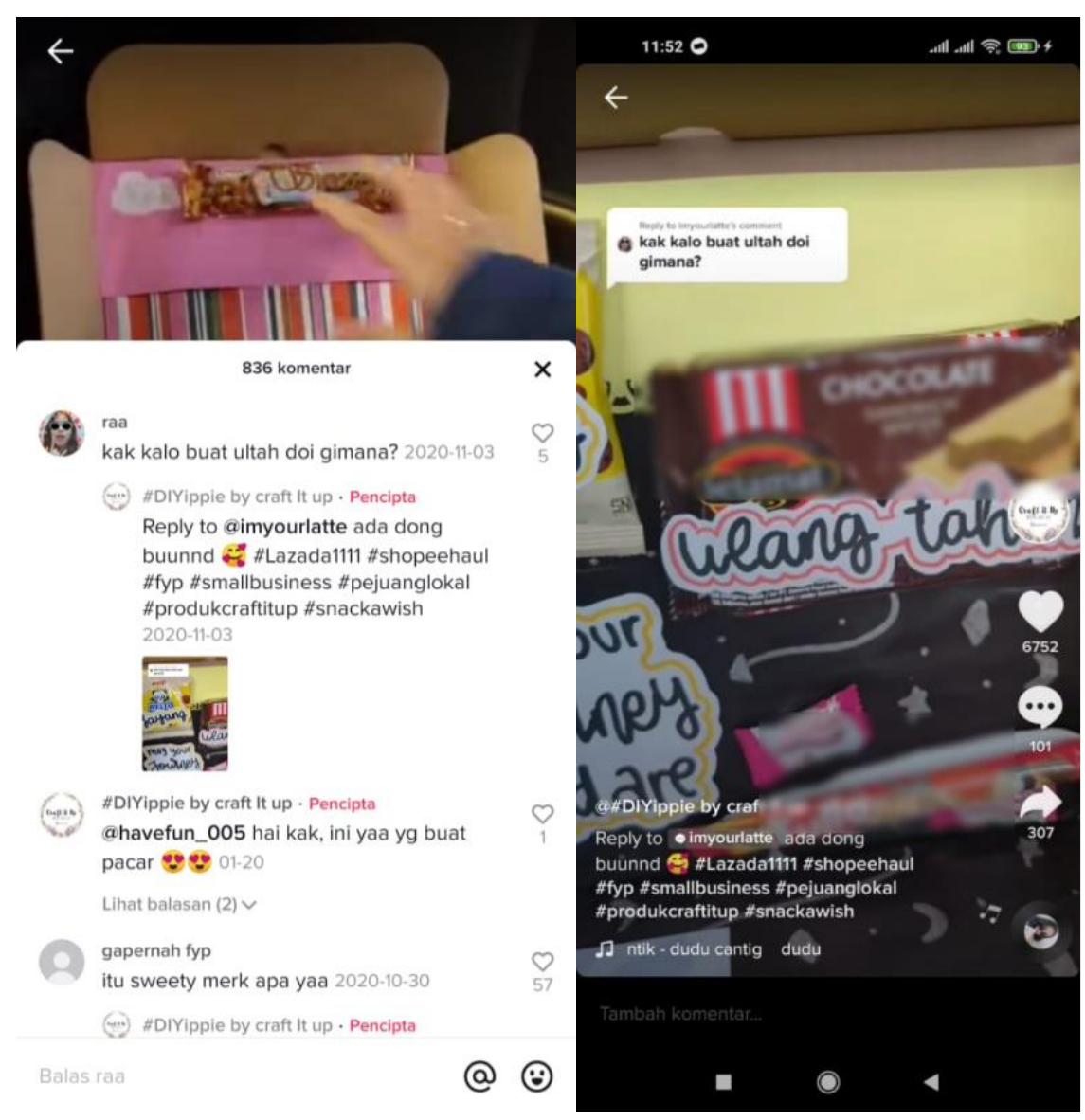

Figure 3. Content of comments (source: TikTok account @Craftitup)

After the idea is determined, a message is designed by MSME actors to convey something to their target market. The messages conveyed include providing information related to the product or target audience, conveying about the product directly, showing the production process, conveying superior products with details to be conveyed, packaging the products they sell before sending to buyers, and answering audience questions on the website's comment field using video. The message conveyed is also soft selling, not directly selling its products to increase the MSME actors' brand awareness. This was said by BA, the owner of the Golden Bees account.

"Video content is not a hard-selling promotion. It is more of a soft selling nature, providing some information, for example how to take product photos, how to live a healthy life or other health tips that relate to the product and the target audience. (BA interview, 03/12/2020)

In making TikTok videos by MSME actors in this study, they did not use standard scripts because they were only more focused on the products they displayed for the audience. MSME actors who are resource persons in this research usually make a content plan containing idea points, concepts tailored to the product, the goods to be shown, and notify the promo.DM, the Kimya id business owner, said.

"There is no manuscript, but preparing a content plan will be like, it can be from the characteristics of the material, introducing promos, introducing products. "(DM interview, 20/01/2021) 


\section{Communication Style}

The delivery of messages is done to attract the audience's interest to pay more attention to the message that MSME actors will convey. The style of communication and sound used must adapt to the platform's characteristics, the audience, and the situation(Kraus et al., 2019). Various types of communication are carried out on TikTok, namely comedy, documentary, communal, explanatory, interactive, and meta video (Schellewald 2021). MSMEs can use this type of communication to introduce their products to potential customers.

The communication style must be planned, namely the way of delivering messages to the communicant starting from the approach, choice of words, and equipment that supports communication, must be prepared by MSME actors so that the message is conveyed correctly. Every MSME actor certainly has their views or specific strategies for conveying messages because currently, there is a lot of video content on TikTok from various existing content creators. Therefore, MSME actors must compete to get the audience's attention, even participate in such comments, likes, sharing the content with others, or even being directly interested in buying the products offered by MSMEs. There are several content strategies that researchers found from several MSME actors in this study, namely:

1. Content that relates to the audience

This content contains informative education related to the products being sold or in direct contact with the audience. Content about experiences also becomes interesting and has a high level of virality. Therefore it is not uncommon for MSME actors to also share their experiences. As research conducted by (Öztamur and Karakadilar 2014) said, when communicating with their prospective customers, they had to use the "human touch." Hence, there was no need to promote as a company continuously.

2. Clear, concise content

Nowadays, people have low stopping power. So, it needs to make short content of no more than thirty seconds by covering some things that someone might want to highlight, such as the product, production process, or packaging. The content is made for 30 seconds so that the audience does not feel bored while watching.

3. Following the trend

The content that is created focuses on following existing trends through the type of content, sound, and hashtags used. All focus on following trends by indeed still linking the products that MSME actors sell to customers.

4. Focus on product

The content presented to the audience contains products ranging from the production process, the materials used, details about the product, the unique side of the product, the use of the product, and the various products sold.

5. Engaging the audience

Content created following the wishes of the audience, starting from comments, orders from customers, and audience requests and distributing gifts to the audience. If the audience is involved in content created by MSME actors, they will be happier and continue to follow the content created by MSME actors. 
Communication style is not only about how the delivery of messages is done but also relates to the equipment used for delivering messages by communicators. In this context, some tools are used by MSME actors in this research to create content and as a supporter to convey the message well to the audience. They include ring light/lighting, products, background photos, and photo properties. MSME actors often share highquality images and videos to attract viewers through social media(Öztamur and Karakadilar 2014).

The method of delivery or communication style used by MSME actors in this study is to prioritize the quality of content and interaction with their audience. The quality of the content starts from the message content, image quality, video aesthetics, and the duration of the video delivered to the audience. On the interaction side, it is needed to increase closeness to the audience and increase the journey of the content so that it can be spread even more to all TikTok users. Not only the journey of one content but the audience will expect for the following content.

\section{Content Schedule}

One of the biggest challenges for SMEs is to upload content regularly. The thing to prevent these obstacles by using the content schedule (Kraus et al. 2019). One important element in message delivery in social media marketing is the content schedule or when content is uploaded through social media. This is important because if we choose the right time to upload content, it will increase the number of viewers of our content organically and be directed to the intended target market. In this case, MSME actors choose the time to upload videos to increase the number of viewers of their videos. Uploading content on social media at $8 \mathrm{pm}$ and midnight will get the highest number of likes, while at noon and $4 \mathrm{pm}$ will get several likes that are less than the average (Pollaka and Dorčakb 2016). Nevertheless, MSMEs here are trying to find their own time for their business.

The schedule for uploading this video is quite different for each business due to several factors, namely differences in target markets, content preferences, and the TikTok algorithm. Some MSME actors have yet to find a specific time to upload videos. However, it is not uncommon for MSME actors to have managed to find effective hours for them to upload content which ultimately increases the number of their audience drastically. If one has a clear content schedule, it will increase engagement in the interaction on a content (Toombs 2014)

For the intensity of delivering messages in a day, the MSME actors in this study usually upload one to three videos a day to stay connected with the audience. For those who have difficulties creating content, the intensity will usually be reduced from three to one content a week. There must be consistency in delivering messages through content from MSME actors themselves. The TikTok algorithm can judge if their account is indeed active and distributed to more other users and displayed in FYP.

\section{Customer Engagement}

After the content is distributed through the TikTok content distribution platform, at this stage, MSME actors already have various experiences they have gone through in conveying messages through content on TikTok. The next thing is to enter the For You Page (FYP) timeline, which MSMEs have always wanted. There are several ways for content to penetrate FYP on TikTok: following trends, content quality, content types, and interactions. 
Several MSME actors in this study have their benchmarks for their content to measure whether the content is effective or not and successful or not, namely when the audience is above ten thousand viewers. If it reaches above that number, it means that the content they create can be well received and liked by the audience, although not all of the content has the opportunity to reach that number.

The involvement of the audience does not stop there. Every comment that comes in on content owned by MSME actors will help them spread their content to TikTok users more broadly. Therefore the involvement of the audience or customers plays a very important role. When viewers can provide feedback such as comments, they will feel engaged in the content. Feedback can contain criticism, praise, or suggestions and give the viewer a sense of community(Mangold and Faulds 2009). Suppose MSME actors only continue to create content without customer involvement, such as commenting, giving likes, or following the account. In that case, the content will not spread wider and make the content "die" because the number of viewers will stop there. For the interaction to continue, MSME actors in this study have ways to keep the interaction going, such as commenting on comments that enter content, creating content from incoming comments, and giving viewers prizes for doing things such as liking, sharing, and commenting on that content. Focus on building relationships rather than selling will increase sales better later. The deeper one builds relationships through content (Broechemier, Chau, and Seshadri 2015).

\section{MSME Message Delivery Model Through TikTok}

After knowing about the content creation elements of MSME actors in this study to carry out marketing communications through the TikTok content distribution platform, a communication model is formed to represent the communication structure carried out. In the context of this research, MSMEs are doing marketing through TikTok.

In marketing, through social media, there are elements of content creation that are very important, namely the target audience, customer participation, content quality, content schedule, and ways of communicating. (Kraus et al. 2019). In accordance with these elements, the authors formulate a communication model that can make it easier for MSME actors to carry out marketing communications through social media, namely as follows:

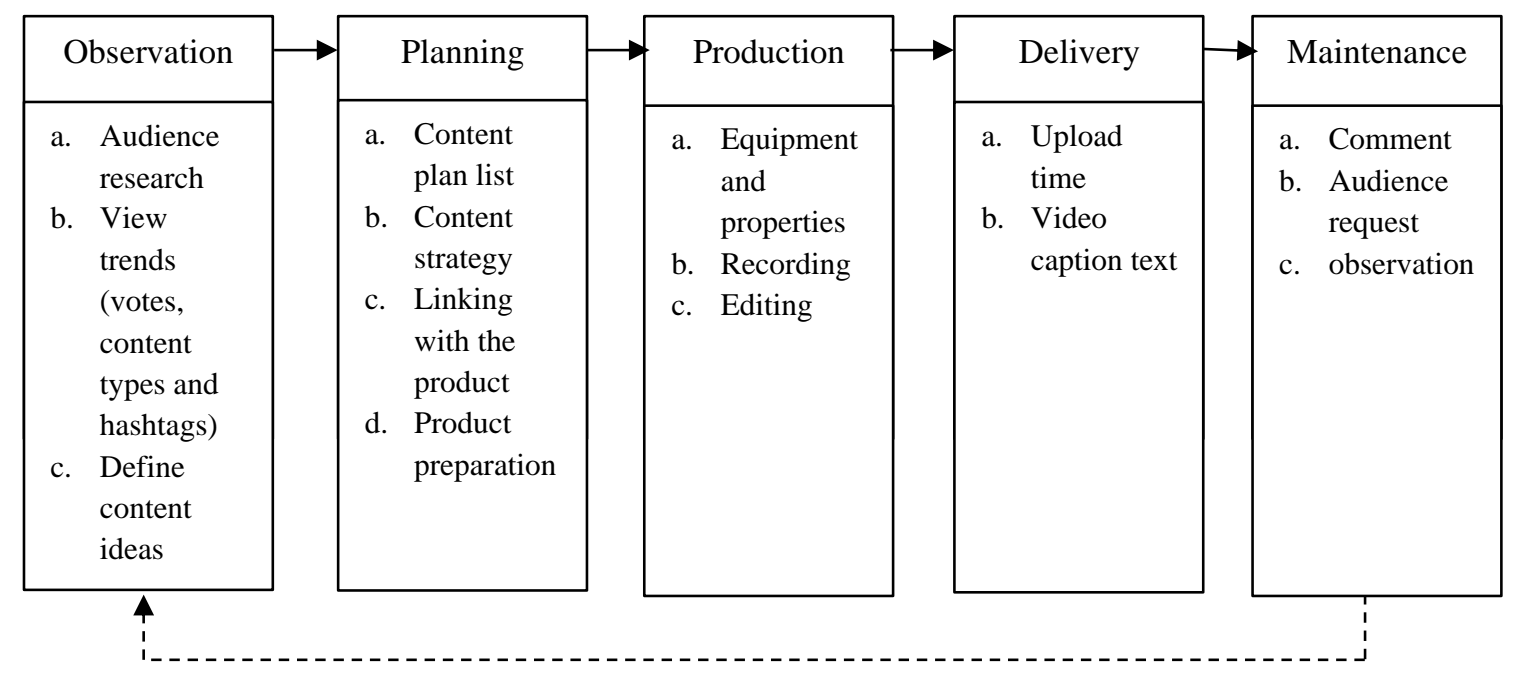

Figure 4. Stages of Message Delivery by MSMEs via social media TikTok 
a. Observation

At this stage, MSMEs conduct in-depth research on the target market and what types of audience they will target and have the opportunity to market the products they sell. The research conducted by (Kraus et al. 2019) explained that the target audience of MSME actors is different because it needs to be understood before creating content. After that, MSME actors observe what content is on FYP or trending among TikTok users. From the existing trends, it is only then to determine what content ideas will be produced according to trends or ideas obtained from sources, not only focusing on the TikTok application.

b. Planning

After observing and finding ideas for what kind of content will be created, MSMEs make a list of content plans that contain points from the idea search and observation process. The content will be implemented into the products offered directly to the target audience. After that, a content strategy will be created, whether the content is to increase brand awareness, sell products or provide educational information to the audience. After that, MSME actors prepare products that they will use for content, which can be obtained from special production for content, have customers, or indeed the products they market.

c. Production

At the production stage, equipment for image recording must be prepared to maintain good video quality, which will keep viewers awake on the content they have, such as cameras, lighting, and tripods. On the content creation element, according to Kraus et al. (2019), there is a content quality component so that the content attracts more viewers. In order for the videos shown to the audience to be more attractive, the use of properties must be considered to make videos of higher quality, more attractive, and liked by the audience, not forgetting to use the products offered to potential customers. After that, the recording is conducted using a camera or smart phone according to the content concept that has been planned. After recording the image, the video will be edited through the video editing application or directly through the TikTok application. Editing here means compiling videos, adding sound, and providing narration and text to support video content.

d. Delivery

After the video has been completed, the next step is to deliver the content through social media. Before the video is uploaded via TikTok social media, the video is given a caption or video description text as an addition to the description and message to be conveyed, and a hashtag is added to help the content spread more widely to all TikTok users. Before uploading, MSME actors enter the video into the draft place on TikTok while waiting for the right time to upload the video. It is very important to determine the video's upload time when submitting the video to increase the likelihood that the video will be seen by more people and can appear in the FYP of many people.

e. Maintenance

At this maintenance stage, a video content has been uploaded via TikTok, which is in the next stage the video, is maintained content such as replying to existing comments. This is done, so that good interaction with the audience appears. Replying to comments can be done by using text and videos, which can eventually be used as content again in the future. This is what is meant by audience requests, 
where a comment can be made into content by MSME actors by replying to comments and following audience requests, making the content more exciting and attractive. Content maintenance can also be used as a re-observation, namely through comments that MSME actors can do more in-depth research to recognize the will of the audience, starting from creating content or developing their business products.

To create effective content marketing, the model used is to create a content strategy, production, distribution, and promotion, measuring content performance (Koob 2021). From the stages of delivering messages that were discussed previously, a model for delivering marketing communication messages carried out by MSME actors through TikTok social media was formed, namely.

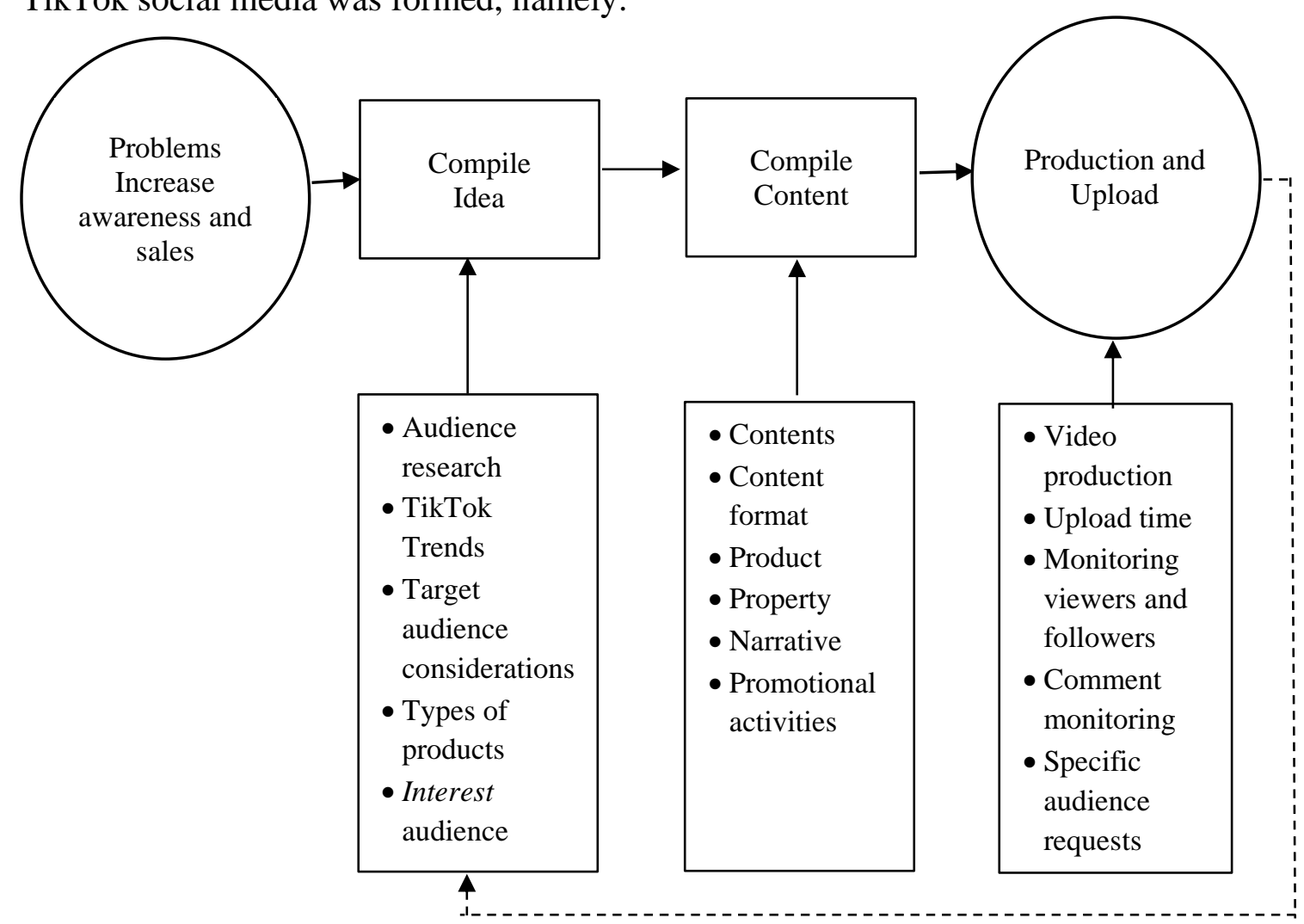

Figure 5. Marketing Communication Message Delivery Model by MSMEs via social media TikTok

The marketing communication model begins with the problems experienced by MSME actors, namely increasing awareness of their business brand and increasing sales of their products and services. To solve this problem, MSME actors create content to carry out marketing communications to their target market. The process begins with developing ideas by looking at the audience, paying attention to trends on TikTok, the type of product to be conveyed, audience interest, and buying behavior from the target market. From these existing ideas, MSME actors compose content by paying attention to the content and the content's format to be delivered. A creator should not forget to pay attention to the products, properties used, narratives, and promotional activities. After the content has been designed, content is produced and uploaded through TikTok with respect to upload times and monitoring viewers, followers, and comments. 
Through comments, MSME actors can see the audience's special requests that can be used as further content ideas. All existing content will be evaluated and determine future content creation, looking at the number of viewers and buying interest from the audience.

\section{Conclusion}

The content creation strategy presented by MSME actors in this study begins with determining their target market: Generation Z. This generation is characterized by growing intelligence, skilled in using technology, creative, and critical. It is not enough for them to see something from just one picture, therefore making a video will give a more comprehensive view of a product that MSMEs offer. The quality of content provided by MSME actors is always oriented to existing trends and their target market. This communication style does not offer a product directly but connects with their audience to get them interested in that content and the content that follows.

The content schedule is usually different for each MSME actor because each business's target market is different. The content schedule is obtained after repeated experiments carried out by MSME actors until they find the ideal time for them and their target audience. Customer engagement is very important on TikTok, expressed by commenting and giving likes. Also, the duration of watching is a significant enough influence that makes the content spread more widely, or even the content can be "dead" and will not increase the number of viewers anymore.

The message delivery model through TikTok begins with the problem of increasing awareness and sales of MSME actors. After that, arrange ideas that will be used to create content. After that, compose content, produce and upload content to the content distribution platform TikTok.

\section{Acknowledgements}

The researcher would like to thank all the informants in this research, including Goldenbees.id, Craft it up, Byrequestcraft, Artspace.id, Claudia Project, Honeyboney, Kimya id, and Vinderu Indonesia, for the information and insights provided about the use of TikTok for MSMEs.

\section{References}

Ainin, Sulaiman, Farzana Parveen, Sedigheh Moghavvemi, Noor Ismawati Jaafar, and Nor Liyana Mohd Shuib. 2015. "Factors Influencing the Use of Social Media by SMEs and Its Performance Outcomes." Industrial Management and Data Systems 115(3):570-88.

Al-Fedaghi, Sabah. 2012. "A Conceptual Foundation for the Shannon-Weaver Model of Communication." International Journal of Soft Computing 7(1):12-19.

Aruman, Akhmad Edhy, Nurmala Katrina Panjaitan, Dwi Sadono, and Fakultas Ekologi. 2017. "MODEL KOMUNIKASI UNTUK MEMBANGUN KESIAPAN." 15(2):43-55.

Bengtsson, Maria, and Marlene Johansson. 2014. "Managing Coopetition to Create Opportunities for Small Firms.” International Small Business Journal 32(4):40127.

Broekemier, Greg, Ngan Chau, and Srivatsa Seshadri. 2015. "Social Media Practices among Small Business-to-Business Enterprises." Small Business Institute Journal 11(1):37. 
Derin, T., M. S. Nursafira, R. S. Yudar, N. S. Gowasa, and B. Hamuddin. 2020. "Persuasive Communication: What Do Existing Literature Tells Us About Persuasive Communication Among Students?" Utamax: Journal of Ultimate Research and Trends in Education 2(1):12-18.

Dian, Pertiwi. 2019. "Strategi Komunikasi Persuasif Dalam Meningkatkan Jumlah Debitur Di Pt. Bni (Persero) Tbk Kantor Cabang Padang." Jom Fisip 6:1-14.

Dilon, Cell. 2020. "Tiktok Influences on Teenagers and Young Adults Students: The Common Usages of The Application Tiktok." American Scientific Research Journal for Engineering 68(1):132-42.

Guest, Greg, Emily Namey, and Mario Chen. 2020. "A Simple Method to Assess and Report Thematic Saturation in Qualitative Research." PLoS ONE 15(5):1-17.

Indrawan, Jerry, and Anwar Ilmar. 2018. "Kehadiran Media Baru (New Media) Dalam Proses Komunikasi Politik." Medium 8(1):11-17.

Koob, Clemens. 2021. "Determinants of Content Marketing Effectiveness: Conceptual Framework and Empirical Findings from a Managerial Perspective." PLoS ONE 16(4 April):1-25.

Kraus, Sascha, Johanna Gast, Moritz Schleich, Paul Jones, and Michael Ritter. 2019. "Content Is King: How SMEs Create Content for Social Media Marketing Under Limited Resources." Journal of Macromarketing 39(4):415-30.

Kusniadji, Suherman. 2016. "Strategi Komunikasi Pemasaran Dalam Kegiatan Pemasaran Produk Consumer Goods.” Jurnal Komunikasi 8(1):83-98.

Mangold, W. Glynn, and David J. Faulds. 2009. "Social Media: The New Hybrid Element of the Promotion Mix." Business Horizons 52(4):357-65.

Öztamur, Dilhan, and İbrahim Sarper Karakadilar. 2014. "Exploring the Role of Social Media for SMEs: As a New Marketing Strategy Tool for the Firm Performance Perspective." Procedia - Social and Behavioral Sciences 150:511-20.

Pollaka, František, and Peter Dorčakb. 2016. "The Effective Use of Facebook by Small and Medium-Sized Enterprises Operating in Slovakia." Market-Trziste 28(1):7991.

Prihatsanti, Unika, Suryanto Suryanto, and Wiwin Hendriani. 2018. "Menggunakan Studi Kasus Sebagai Metode Ilmiah Dalam Psikologi." Buletin Psikologi 26(2):126.

Putri, Frieda Isyana, Triyono Lukmantoro, S. Sos, M. Si, Hapsari Dwiningtyas, S. Ma, Drs Joyo, and N. S. Gono. 2015. "Teknik-Teknik Persuasif Dalam Media Sosial (Studi Analisis Isi Kualitatif Pada Akun Mentor Parenting Ayah Edy Di YouTube)." Jurnal Ilmu Komunikasi 1-9.

Ri'aeni, Ida. 2019. "Strategi Komunikasi Pemasaran Digital Pada Produk Kuliner Tradisional." LUGAS Jurnal Komunikasi 1(2):141-49.

Ricko, Ricko, and Ahmad Junaidi. 2019. "Analisis Strategi Konten Dalam Meraih Engagement Pada Media Sosial Youtube (Studi Kasus Froyonion)." Prologia 3(1):231.

Sarfiah, Sudati Nur, Hanung Eka Atmaja, and Dian Marlina Verawati. 2019. "UMKM Sebagai Pilar Membangun Ekonomi Bangsa." Jurnal Riset Ekonomi Pembangunan 4(2):41-52.

Savitri, Syahnaz, and Irwansyah Irwansyah. 2021. "The Use of Instagram Stories at the Age of COVID-19 Pandemic." Jurnal ASPIKOM 6(1):182.

Schellewald, Andreas. 2021. "Communicative Forms on TikTok: Perspectives From Digital Ethnography.” International Journal of Communication 15:1437-57. 
Simangunsong, Eliot. 2021. "Identifying Personal Characteristics of Social Media Entrepreneurs in Indonesia." Jurnal ASPIKOM 6(2):360.

$\mathrm{Su}$, Yiran, and Bradley James Baker. 2020. "Fan Engagement in Fifteen Seconds: Athletes 'Relationship Marketing during a Pandemic via TikTok." (June).

TikTok. 2020. "Inspirasi - TikTok for Business." Retrieved October 21, 2020 (https://www.tiktok.com/business/id/inspiration).

Toombs, Leslie A. 2014. "More Than Just A Like: An Entrepreneurial Approach To Creating A Social Media Ethos In Small Firms." Academy of Marketing Studies Journal 18(2):275.

Vinerean, Simona. 2017. "Content Marketing Strategy. Definition, Objectives and Tactics." Expert Journal of Marketing 5(2):92-98.

Warren, C., S. Becken, and A. Coghlan. 2017. "Using Persuasive Communication to Co-Create Behavioural Change-Engaging with Guests to Save Resources at Tourist Accommodation Facilities.” Journal of Sustainable Tourism 25(7):93554.

Weinberg, Bruce D., and Ekin Pehlivan. 2011. "Social Spending: Managing the Social Media Mix." Business Horizons 54(3):275-82. 